\title{
Implementing Geo Positioning System for Children Tracking Location Monitoring based on Android
}

\author{
Marti Widya Sari' ${ }^{1}$, Banu Santoso ${ }^{2 *}$, Mohamed Nor Azhari Azman ${ }^{3}$ \\ ${ }^{1}$ Department of Informatics, Faculty of Science and Technology, \\ Universitas PGRI Yogyakarta, Indonesia \\ ${ }^{2}$ Department of Computer Engineering, Faculty of Computer Science, \\ Universitas AMIKOM Yogyakarta, Indonesia \\ ${ }^{3}$ Department of Engineering Technology, Faculty of Technical and Vocational \\ Universiti Pendidikan Sultan Idris, Malaysia
}

\begin{abstract}
Purpose: The objectives of this research are to generate a system or application to track the whereabouts of children through smartphones that can be used by both parents of the child, and to design device that can be used practically, and children can be traced to the presence of wireless media by their parents. Improved supervision of children is needed without reducing the freedom of children to learn and explore their environment.

Methods: One alternative that allows tracking the presence, location and accuracy is quite good is to use a Geo Positioning System (GPS).

Result: This GPS is packaged in a flexible form so that it can help make it easier for parents to supervise their children in the range of areas that are still accessible to them and find the child's position when separated from their parents. Novelty: The system can send the location information of children who are lost or lost on smartphone applications used by parents.
\end{abstract}

Keywords: Geo Positioning System, Tracking, Location, Monitoring, Android Received December 2020 / Revised March 2021 / Accepted May 2021

This work is licensed under a Creative Commons Attribution 4.0 International License.

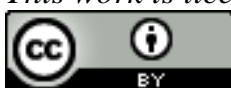

\section{INTRODUCTION}

In terms of the growth of reason, children from the age of four to five years have a great curiosity about the surrounding environment and all information related to it [1]. Children at this age have advantages in the form of an adventurous spirit, high spirits, and like challenges. Children's activities can be divided into two main groups, namely active play and passive play or known as entertainment. Active play is a play activity that involves the child's physical movements and activities, such as running, going up and down stairs, playing sand, and others [2]. Conversely, passive play is entertaining and does not involve child gestures, such as observing other children playing, watching television, and playing video games. The development of a child that is different from one child to another, this is the stage of the child's stage of growth and development [3]. At this stage of growth and development which is in the golden phase tends to be more interested in exploring things around them [4]. When exploring this, children are interested in the surrounding environment, for example in open spaces where parents play an important role in monitoring the activities of children who are outside [5], [6]. Train children to prepare themselves to face this sometimes-dangerous world, first develop a sense of security in themselves. It is natural to occasionally remind a child of the possibility of being abducted or cheated by someone he has not yet known or has known [7]. But it does not mean having to over-protect it. It is not wise to forbid a child from going out the fence, while the child wants to play with neighbors outside the house. Or continue to accompany them in all their activities. Attitudes like this will increase a child's fear of things that are foreign to him.

Increased supervision of children is needed without reducing the freedom of children to learn and explore their environment [8]. For this reason, is needed a tool or system that can help make it easier for parents to supervise their children in the range of areas that are still reachable by them and find the child's position when separated from their parents. Research conducted by [9] about the system of monitoring the location of children using geofencing on the Android platform. This research discusses how geofencing works a virtual perimeter on a geographical area using location services, using the android platform. While the

\footnotetext{
* Corresponding author.

Email addresses: marti@upy.ac.id (Sari), banu@amikom.ac.id (Santoso)

DOI:10.15294/sji.v8i1.27436
} 
author will create applications with the Delphi Embarcadero Xe8 programming and on the web using PHP MySQL. Then the research carried out by [10] about the design of information systems for tracking and monitoring web-based shipment packages with the help of an android mobile, and using GPS to find out the location of tracking and monitoring of shipment packages. Then, research conducted by [11] discusses the use of GPS for use in health research. Research conducted by [12] about assessing the spatial location of physical activity behavior. While the authors will make the tracking and use of Google maps to cover the whole world map and will be more accurate. With the review of the literature listed above, the methods and tools used are generally the same, but what distinguishes the research that will be made by the author is the place or media of application, the materials to be used as well as the objects examined and used as building designs child tracking system using GPS tracker uses technology that will be designed by itself and built on this final project that uses a microcontroller service and android interface as a controller for child tracking [13], [14].

The objectives of this research are to generate a system or application to track the whereabouts of children through smartphones that can be used by both parents of the child, and to design device that can be used practically, and children can be traced to the presence of wireless media by their parents.

\section{METHODS}

\section{System Design}

This system uses the ESP8266 wifi module which is used as an access point to access other devices through the internet network [15]. this device is commonly used in systems that are used based on internet of things (IoT) [16], [17]. The system designed also utilizes GPS technology for tracking, as shown ini Figure 1.

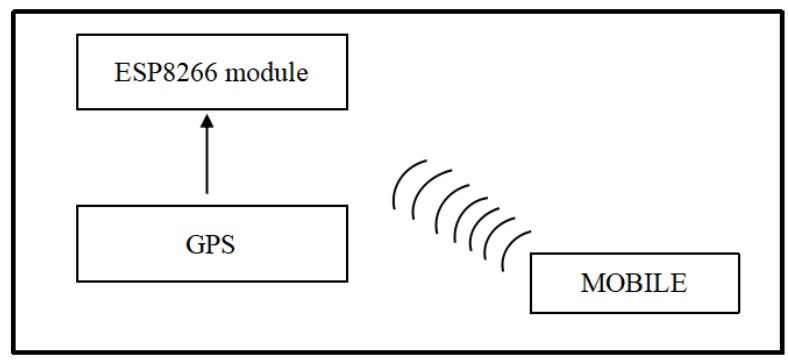

Figure 1. System Design

When tracking first for a child search, GPS sends to ESP8266 the location data of the child's presence. Furthermore, when an order from mobile for tracking is obtained, ESP responds and continues sending data from GPS to mobile.

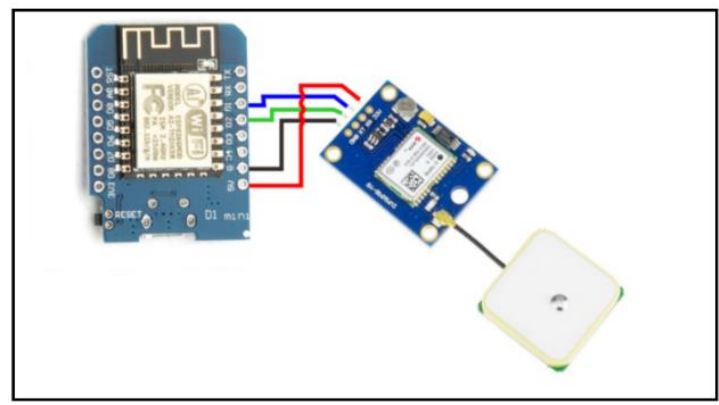

Figure 2. Hardware Design

Figure 2 is the steps or making that is applied to the system and has been arranged in such a way that it is neater. The hardware running after compiled in terms of cabling or connection between hardware, then the coding of the NodeMCU microcontroller is required. The hardware components used are as follows. 


\section{a. GPS Antenna}

The GPS antenna for the Neo 6 GPS module at the top is expected to produce NMEA data from more GPS satellites perfect.

b. Module GPS Neo 6

Laying the Neo 6 GPS module in the middle position between the antenna and the NodeMCU microcontroller. This arrangement is more practical and efficient because the Neo 6 GPS module has communication between the two hardware.

c. Microcontroler NodeMCU

Laying NodeMCU with the lowest position after the antenna module and the GPS module Neo 6. The bottommost position is because the microcontroller works without using signals, only communicates with the GPS module.

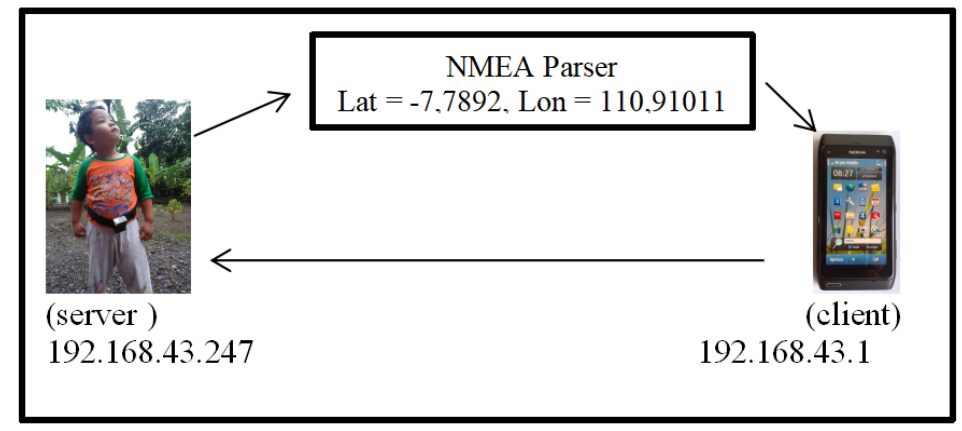

Figure 3. Data Exchange Process

In Figure 3, the Arduino requests data from the neo 6 GPS 6 module, and the neo 6 GPS takes data from the satellite in the form of NMEA data. NMEA data is sent to Arduino and filtered to retrieve location coordinate data only by Arduino. The coordinate data is sent via wireless communication to the smartphone [18], [19]. Coordinate data on smartphones is accessed via google maps which are accessed using the Google Maps API.

\section{System Implementation}

Monitoring system implementation for tracking system application consist of Login Form, Main Menu Form, Child list to be used for tracking and Tracking Form.

a. Login Form

The login form functions to enter the child tracking system menu by the user that is the child's parents, to be able to access the next page the user must enter a username and password that has been registered in the system database.

b. Main Menu Form

On the home menu there is a child search radar as the most important menu contents for the child search process, then there is a menu for adding new users and a list of children that will be monitored by the user. In the home menu, a list of some children registered in the database will be monitored by parents of the child search google map.

c. Child List

On the child list menu is monitoring by the child tracking system, there are several forms that must be filled in there is a name, IP address of the GPS belt attached to the child and the child's birth date. Delphi XE 8 .

d. Tracking Form

In the tracking form a map will appear that points the location of the child the user will be looking for. There are two locations that indicate the whereabouts of parents and missing children. In this menu the user will be directed where to look for his child. The functionality of this form in its implementation is used coding or programming in systems that use the Delphi XE 8 application. 


\section{RESULTS AND DISCUSSION}

Testing is done to test the level of system success. This research was tested by the author himself, assisted by the author's son. The tracking device is used by children and children are told to play with it. Subsequent testing of parents, in this case the author will try to measure and track the IP device is still connected or detected within a certain distance and radius in the presence of a barrier object in the form of a building and the absence of any barrier. The author monitors signal detection by using applications that have been made. Monitoring system testing is carried out in a number of circumstances, for example without obstacles and with obstacles. The barriers used are doors, wall, buildings, and trees. The purpose of testing using obstacles or not is to know that the system can be connected to the source or not. In testing this system is recorded in the test results table presented in the Table 1, Table 2, Table 3, Table 4, Table 5 and Table 6 . The distance used for testing the system is from $5 \mathrm{~m}$ to $50 \mathrm{~m}$, with obstacles and without obstacles.

Table 1. First Testing Result

\begin{tabular}{ccc}
\hline Distance & Obstacle & Status \\
\hline $5 \mathrm{~m}$ & One Building & Connected \\
$10 \mathrm{~m}$ & One Building & Connected \\
$15 \mathrm{~m}$ & One Building & Connected \\
$20 \mathrm{~m}$ & One Building & Connected \\
\hline
\end{tabular}

Table 2. Second Testing Result

\begin{tabular}{ccc}
\hline Distance & Obstacle & Status \\
\hline $5 \mathrm{~m}$ & Two Building & Connected \\
$10 \mathrm{~m}$ & Two Building & Connected \\
$15 \mathrm{~m}$ & Two Building & Connected \\
$20 \mathrm{~m}$ & Two Building & Connected \\
$30 \mathrm{~m}$ & Two Building & Not Connected \\
\hline
\end{tabular}

Table 3. Third Testing Result

\begin{tabular}{ccc}
\hline Distance & Obstacle & Status \\
\hline $5 \mathrm{~m}$ & Three Building & Connected \\
$10 \mathrm{~m}$ & Three Building & Connected \\
$15 \mathrm{~m}$ & Three Building & Connected \\
$20 \mathrm{~m}$ & Three Building & Connected \\
$25 \mathrm{~m}$ & Three Building & Not Connected \\
\hline & & \\
\hline Distance & Table 4. Fourth Testing Result \\
\hline $5 \mathrm{~m}$ & Obstacle & Status \\
$10 \mathrm{~m}$ & $2^{\text {nd }}$ Floor Building & Connected \\
$15 \mathrm{~m}$ & $2^{\text {nd }}$ Floor Building & Connected \\
$20 \mathrm{~m}$ & $2^{\text {nd }}$ Floor Building & Connected \\
$25 \mathrm{~m}$ & $2^{\text {nd }}$ Floor Building & Connected \\
$35 \mathrm{~m}$ & $2^{\text {nd }}$ Floor Building & Connected \\
$40 \mathrm{~m}$ & $2^{\text {nd }}$ Floor Building & Connected \\
$45 \mathrm{~m}$ & $2^{\text {nd }}$ Floor Building & Connected \\
& $2^{\text {nd }}$ Floor Building & Not Connected \\
\hline
\end{tabular}


Table 5. Fifth Testing Result

\begin{tabular}{ccr}
\hline Distance & Obstacle & Status \\
\hline $5 \mathrm{~m}$ & Trees & Connected \\
$10 \mathrm{~m}$ & Trees & Connected \\
$15 \mathrm{~m}$ & Trees & Connected \\
$20 \mathrm{~m}$ & Trees & Connected \\
$25 \mathrm{~m}$ & Trees & Connected \\
$35 \mathrm{~m}$ & Trees & Connected \\
$40 \mathrm{~m}$ & Trees & Connected \\
$45 \mathrm{~m}$ & Trees & Connected \\
$50 \mathrm{~m}$ & Trees & Not Connected \\
\hline
\end{tabular}

Table 6. Sixth Testing Result

\begin{tabular}{ccr}
\hline Distance & Obstacle & Status \\
\hline $5 \mathrm{~m}$ & Wall/Fence & Connected \\
$10 \mathrm{~m}$ & Wall/Fence & Connected \\
$15 \mathrm{~m}$ & Wall/Fence & Connected \\
$20 \mathrm{~m}$ & Wall/Fence & Connected \\
$30 \mathrm{~m}$ & Wall/Fence & Connected \\
$35 \mathrm{~m}$ & Wall/Fence & Connected \\
$40 \mathrm{~m}$ & Wall/Fence & Connected \\
$45 \mathrm{~m}$ & Wall/Fence & Connected \\
$50 \mathrm{~m}$ & Wall/Fence & Not Connected \\
\hline
\end{tabular}

The tables above are test results based on distance and radius trials in detecting devices with applications whether connected or not when there are obstacles in the form of buildings, buildings and trees.

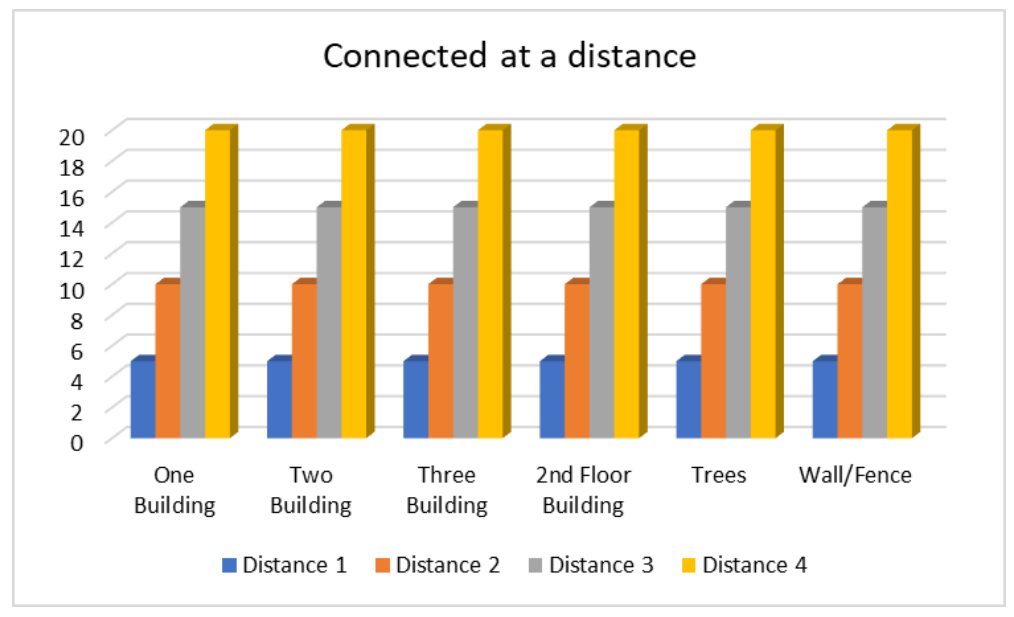

Figure 4. Connected at each distance 


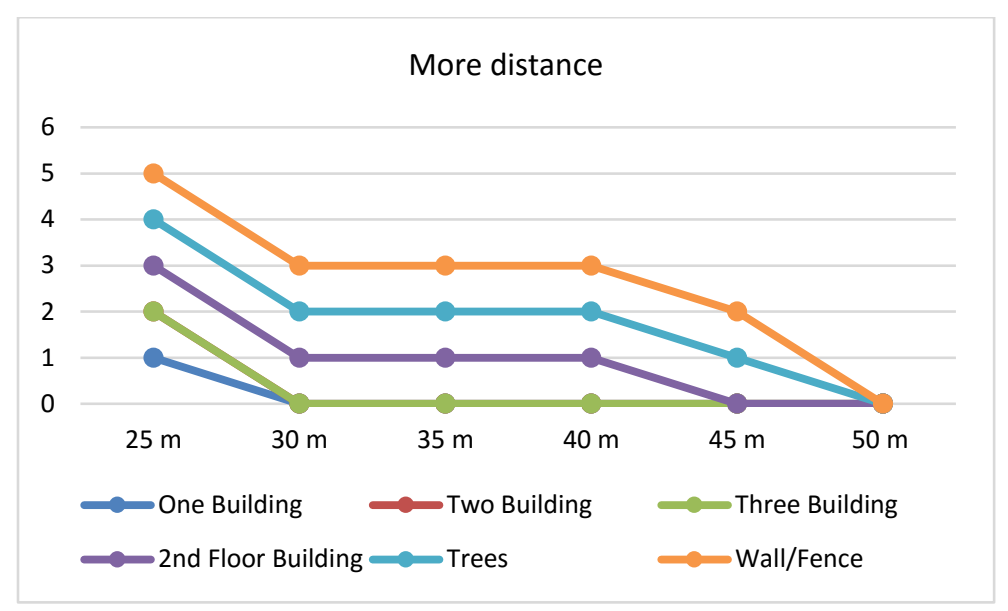

Figure 5. More distance for each obstacle

In Figure 4 it can be seen that for the obstacle in the form of one building, two building, three building, 2nd floor building, trees and wall/fence, the device is still connected at a distance of 5 to 20 meters. In Figure 5 , the test results for a longer distance are shown. At a distance of 50 meters, the device is disconnected for all obstacles.

\section{CONCLUSION}

From the series of research and testing tools that have been done on the author, it can be concluded that the creation of a child's tracking system through a smartphone has been running and succeeded with a good success rate and in accordance with the system design concept and can be used by both parents of the child because the display is easy to understand overall. Then, making the system devices can be used comfortably like a practical child belt and can be tracked by the child's presence on the wireless media by his parents. System testing has been carried out, both using obstacles or without obstacles, and with different distances, ranging from 5 meters to 50 meters. The obstacles used for system testing are doors, walls, fences, buildings, and trees. The monitoring system in this study, only carried out for testing at a maximum distance of 50 meters. For further research, a tracking application for the location of children can be designed that can reach longer distances, more than 50 meters. Then it can be added with other features and information related to the location search of children.

\section{REFERENCES}

[1] D. G. Rainham, C. J. Bates, C. M. Blanchard, and T. J. Dummer, "Spatial Classification of Youth Physical Activity Patterns,” AMEPRE, vol. 42, no. 5, pp. e87-e96, 2012.

[2] X. Yang, R. Jago, Q. Zhang, Y. Y. Wang, and J. Zhang, "Validity and Reliability of the Wristband Activity Monitor in Free-living Children Aged 10-17 Years," Biomed. Environ. Sci., vol. 32, no. 11, pp. 812-822, 2019.

[3] T. Disney et al., "'Isn't it funny the children that are further away we don't think about as much?": Using GPS to explore the mobilities and geographies of social work and child protection practice," Child. Youth Serv. Rev., vol. 100, pp. 39-49, 2019.

[4] C. Demant Klinker, J. Schipperijn, M. Toftager, J. Kerr, and J. Troelsen, "When cities move children: Development of a new methodology to assess context-specific physical activity behaviour among children and adolescents using accelerometers and GPS," Heal. Place, vol. 31, pp. 90-99, 2015.

[5] I. Fjørtoft, B. Kristoffersen, and J. Sageie, "Children in schoolyards: Tracking movement patterns and physical activity in schoolyards using global positioning system and heart rate monitoring," Landsc. Urban Plan., no. 93, pp. 210-217, 2009.

[6] G. Bekö, B. U. Kjeldsen, and Y. Olsen, "Contribution of various microenvironments to the daily personal exposure to ultra fi ne particles : Personal monitoring coupled with GPS tracking," Atmos. Environ., no. 110, pp. 122-129, 2009.

[7] B. W. Landry and S. W. Driscoll, "Theme Issue : Exercise and Sports Physical Activity in Children and Adolescents," PMRJ, vol. 4, no. 11, 2012.

[8] E. Almanza, M. Jerrett, G. Dunton, E. Seto, and M. Ann Pentz, "A study of community design, 
greenness, and physical activity in children using satellite, GPS and accelerometer data," Heal. Place, vol. 18, no. 1, pp. 46-54, 2012.

[9] R. Segara, "Sistem pemantauan lokasi anak menggunakan metode geofencing pada platform android," Teknol. Manaj. Inform., vol. 3, no. 1, pp. 72-85, 2017.

[10] P. A. Y. Indrakarna, T. Sutanto, and V. M. Taufik, "Rancang Bangun Sistem Informasi Pelacakan Dan Pemantauan Paket Kiriman Berbasis Web Dengan Bantuan Mobile Android," J. JSIKA, vol. 1, no. $2,2012$.

[11] J. Schipperijn, J. Kerr, S. Duncan, and T. Madsen, "Dynamic accuracy of GPS receivers for use in health research : a novel method to assess GPS accuracy in real-world settings," Front. Public Heal., vol. 2, pp. 1-8, 2014.

[12] P. J. K. DI Mag, S. Titze, and P. Oja, "Use of Global Positioning Systems to Study Physical Activity and the Environment," AMEPRE, vol. 41, no. 5, pp. 508-515, 2011.

[13] B. W. Wheeler, A. R. Cooper, A. S. Pag, and R. Jago, "Greenspace and children 's physical activity: A GPS / GIS analysis of the PEACH project," Prev. Med. (Baltim)., vol. 51, no. 2, pp. 148-152, 2010.

[14] S. Duncan, T. I. Stewart, M. Oliver, and S. Mavoa, "Portable Global Positioning System Receivers," AMEPRE, vol. 44, no. 2, pp. e19-e29, 2013.

[15] B. Santoso, "Implementasi Wireless Sensor and Actuator Network Berbasis Protokol Zigbee Untuk Pemantauan Dan Pengendalian Smart Home,” J. Din. Inform., vol. 7, no. 1, pp. 13-31, 2018.

[16] B. Santoso and M. W. Sari, "Design of Student Attendance System Using Internet of Things (IoT) Technology," J. Phys. Conf. Ser., vol. 1254, no. 1, 2019.

[17] S. N. Kane, A. Mishra, and A. K. Dutta, "Preface: International Conference on Recent Trends in Physics (ICRTP 2016)," J. Phys. Conf. Ser., vol. 755, no. 1, 2016.

[18] R. P. Kristianto, B. Santoso, and M. W. Sari, "Integration of K-means clustering and naïve bayes classification algorithms for smart ac monitoring and control in WSAN," 2019 4th Int. Conf. Inf. Technol. Inf. Syst. Electr. Eng. ICITISEE 2019, pp. 495-500, 2019.

[19] B. Santoso, A. E. Permanasari, and A. Bejo, "Perbaikan Waktu Tunggu Pelayanan Pasien Rumah Sakit Menggunakan Teknologi RFID dan WSN," Semin. Nas. Teknol. Inf. dan Komun. 2016 (SENTIKA 2016) Yogyakarta, 18-19 Maret 2016, vol. 2016, no. Sentika, pp. 658-665, 2016. 